\author{
Svetlana R. Stojić ${ }^{1}$
}

University of Belgrade

Faculty of Philosophy

\title{
I KNOW WHERE THE BEST ENGLISH IS SPOKEN: SOME SERBIAN STUDENTS' PERCEPTIONS OF AND ATTITUDES TOWARDS THE VARIETIES OF ENGLISH
}

\begin{abstract}
This paper presents some of the results of two questionnaire surveys into students' perceptions and overt attitudes towards varieties of English. The first survey was conducted in 1997 and was replicated in 2016. The primary purpose of this comparative study is to examine the differences and similarities in perceptions and attitudes expressed by the two generations of first-year students of English separated by a span of nineteen years. The paper focuses on the results related to attitudes towards British and American English as well as to perceptions of the 'best' English. The comparison of the results has revealed some differences as well as two key similarities: the majority of respondents in both surveys expressed positive attitudes towards American English but they also shared the view that the 'best' English was spoken in Great Britain.

Keywords: survey, language attitudes, perceptions, British English, American English, varieties
\end{abstract}

\section{INTRODUCTION}

Despite the upsurge of interest in research on English as a lingua franca (ELF) in recent decades (e.g. Jenkins 2014: 24), standard British and standard American English are still the two preferred models amongst many learners of the language all over the world (e.g. Galloway and Heath 2015). The view that British and American English are the two most legitimate models in TEFL is also shared by teachers (Jenkins 2007: 197), educators and by foreign-language policy makers in many countries.

Serbia is not an exception in this respect, as standard British English and standard American English are the two reference norms taught in institutions of formal and informal education, though British English was the dominant model until comparatively recent times. Today, either of these two standard varieties may be prescribed or recommended as a teaching model by a learning institution, but more often than not it is the teacher of English who decides which of the two norms should be taught in the classroom.

The process of learning English as a foreign language, however, need not begin or end in educational institutions. As Prćić (2014) explains, English is learned both institutionally and uninstitutionally. Owing to the global pro-

1 sstojic@f.bg.ac.rs, svstojic@gmail.com 
cess of "mediatisation" (see Androutsopoulos 2014), nowadays, more than ever, learners are (potentially) exposed to many varieties of English through traditional media such as television (see Bilankov 2002, Dragojevic at al 2016), and increasingly through the so-called new (digital) media.

It is important to note, though, that both school and the media are the two main agents of language attitude socialisation and as such they shape learners' attitudes towards both native and non-native varieties of English. These attitudes, in fact, reflect social perceptions of the speakers of these varieties.

\section{LANGUAGE ATTITUDES RESEARCH}

The use of particular languages, dialects and accents, called speech styles or speech varieties, induces listeners' evaluative reactions. These evaluative reactions are attitudinal expressions. Attitude is very broadly defined as "a psychological tendency that is expressed by evaluating a particular entity with some degree of favor or disfavor" (Eagly and Chaiken 2014: 749). This definition of attitude "distinguishes between the inner tendency that is attitude and the evaluative responses that express attitudes" (Eagly and Chaiken 2007: 582).

Since the 1960s when the social psychologist Wallace Lambert and his colleagues (Lambert et al. 1960) and the sociolinguist William Labov (1966) blazed a trail in language attitude studies, a substantial amount of language attitudes research has been conducted using various approaches and techniques (for an overview see e.g. Garrett 2010).

The matched-guise technique (MGT), originally developed by Lambert, has been most widely used for indirect assessment of attitudes by means of speaker evaluation. In the studies using this technique, listeners-judges are told that they are going to hear the voices of different speakers. In fact, they listen to the same speaker reading the same paragraph two or more times each time using a different speech style called a guise. Judges evaluate each guise on attitude-rating scales or bipolar-adjective scales. This technique enables the researcher to manipulate speech style while controlling other factors that might affect the assessment. The manipulations may be in terms of particular languages, dialects and accents, although accents (regional, social, ethnic etc.) have received most attention in research studies on varieties of English (see e.g. Giles and Rakić 2014: 11).

The MGT and its adapted and modified variant form called the verbal-guise technique (e.g. using different speakers for contrasted speech styles) have been widely utilised to elicit information on how a speaker of a particular language or a given variety is perceived, thus enabling indirect assessment of attitudes by means of speaker evaluation. A series of studies has suggested multidimensionality of attitudes, with two most salient evaluative dimensions i.e. that of social status (e.g. intelligence, competence, social class) and solidarity (e.g. pleasantness, social attractiveness, trustworthiness). These studies have also demonstrated that standard and non-standard varieties induce different evaluations along these dimensions with standard speakers usually 
being evaluated favourably on status dimension but not on solidarity (see e.g. Giles and Marlow 2011).

Whilst the use of the MGT and VGT aims at eliciting implicit attitudes that respondents may not be aware of, questionnaires, interviews and techniques developed within perceptual or folk dialectology studies (e.g. mapping techniques) are used for direct elicitation of explicit attitudes. Direct and indirect attitude measures are often combined in a study to enable cross-validation of results.

In an early investigation that Giles (1970) conducted in the UK using the MGT, a matched guise (male) voice performed thirteen regional, social and foreign accents of English. The respondents were required to rate their "aesthetic", "communicative" and "status" contents on scales. In the same study Giles also used questionnaires in which accents were presented conceptually i.e. 16 different labels of accents served as stimuli and respondents again rated them on scales. This and similar subsequent studies have revealed much greater prestige attributed to Received Pronunciation (RP) than to regional and foreign accents.

In a more recent online survey (Bishop et al 2005, Coupland and Bishop 2007), 5010 informants from across the UK evaluated 34 accent varieties presented to them in the form of speech variety labels. The informants judged the "prestige" and "pleasantness" of each accent on two seven-point scales. Two accents associated with RP, labelled "Queen's English" and "A standard accent of English", were accorded the highest prestige but were not rated uniformly in terms of pleasantness, since the designation "Queen's English attracted more mixed evaluations for attractiveness" (Coupland and Bishop 2007: 85). The findings were also contrasted with those obtained in the aforementioned Giles's study (1970), revealing "some interesting differences" but also showing "a remarkable similarity with those of Giles" (Bishop et al 2005: 131).

In recent decades non-native speakers' attitudes towards native and non-native varieties of English have also been extensively researched in many countries across the globe. The results of most of these studies have also indicated that standard British and American accents are more highly evaluated in terms of prestige, but not always in terms of solidarity or social attractiveness (see e.g. Jenkins 2007; Galloway and Heath 2015).

\section{THE PRESENT STUDY: INSTRUMENTS AND METHODS}

The present study is a comparative analysis of the results emanating from two surveys into students' perceptions of and overt attitudes towards varieties of English. The instrument used in the study is a paper-based questionnaire designed in 1996. It comprises both open-ended and close-ended questions as well as a number of agree-or-disagree statements, most of which offer a binary response option.

In 1997 the questionnaire was administered to 152 first-year students of English (16 male, 136 female, aged 18-28, M = 19.35) at the English Depart- 
ment of the Faculty of Philology, Belgrade University. At the time this sample was a subset of a larger sample (see Stojić 2005).

The survey was replicated in 2016. The same questionnaire was distributed to 120 first-year students of English (25 males, 95 females, aged 18-24 years, $M=19.27$ ) at the English Department of the same Faculty.

The participation in both surveys was voluntary and the questionnaires, written in Serbian, were filled out anonymously.

The primary purpose of this comparative study is to examine the differences and similarities in perceptions and attitudes expressed by the two generations of first-year students of English separated by a nineteen-year span.

This paper briefly touches upon the results related to the overtly expressed attitudes towards British and American English, the perceived degree of their mutual intelligibility and the influence of Americanisms on British English. It also sheds light on respondents' reported perceptions of their own speech variety, the evaluative judgements about the 'best' English and its speakers, as well as on the perceptions of the most socially acceptable accent in the UK. Since the data were analysed using descriptive statistics, the results are presented as percentages, and where appropriate, as frequencies.

\section{RESULTS AND DISCUSSION}

The questionnaire asked the respondents to report the variety of English they spoke. Answering this close ended question, they could choose between Standard British and Standard American English, or state any other variety of English.

The results of the 2016 survey indicate that $61.7 \%$ of respondents reported they spoke Standard American English, while 30\% stated they spoke standard British English. Only 8.3\% $(n=10)$ claimed to speak other varieties, six of whom reported they spoke a mixture of British and American English. One student stated she spoke a mixture of Australian and American English, while another claimed he spoke Cockney. The remaining two respondents did not specify the variety they spoke, explaining they had not decided yet which one to master.

In stark contrast, the results of the 1997 survey reveal a completely inversed picture, for $78.9 \%$ of the respondents reported they spoke standard British English, 15.8\% standard American English, 3.3\% a mixture of the two aforementioned varieties, while two respondents did not answer the question (see figure 1). 


\section{Figure 1 WHICH VARIETY OF ENGLISH DO YOU SPEAK?}
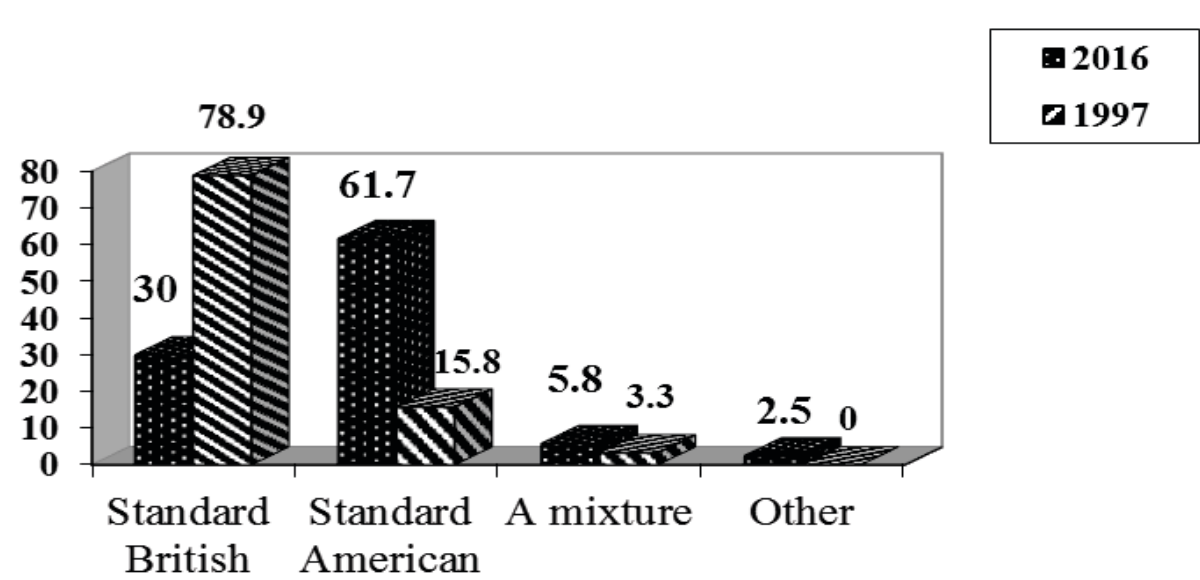

The striking difference between the above presented results is not surprising (e.g. Paunović 2009, Rindal 2010; Stojić 2013, Edwards 2016), as young people throughout the world are increasingly exposed to American English through the media and popular culture.

These results should be taken with caution though, for some previous studies have shown that reported speech styles of respondents can be different from their actual linguistic behaviour (e.g. Labov 1966, Trudgill 1974). Therefore, these findings should rather be seen as suggestive, possibly indicating the students' conscious aspirations to sound as native speakers of the variety they reported.

Aiming at a particular native-speaker-like speech style may also be one of the reasons why a very low percentage of respondents from both surveys stated they spoke a mixture of (Standard) British and American English, although using some mixture of the two varieties is a common tendency amongst language learners (e.g. Rindal and Piercy 2013) and even amongst some native speakers of English (Trudgill and Hannah 2013: 6). Another reason may be that a mixture of the two aforementioned varieties was not offered as an explicit response option. Moreover, a mixture of the two varieties is not always tolerated in ELT settings, requiring learners to use only one specific variety of English (e.g. Čorbić 2011: 408).

Regardless of the variety the respondents from both surveys reported they spoke, the great majority of them (82.5\% in the 2016 survey vs. $70.4 \%$ in the 1997 survey) agreed with the statement that 'American English is as good as British English'.

The majority of respondents in both surveys (78.3\% in 2016 and $64.5 \%$ in 1997) also agreed with the statement that 'British English and American English are mutually intelligible', whereas $21.7 \%$ and $34.9 \%$, respectively, thought that the two varieties were partly mutually intelligible. None of the respond- 
ents in both surveys disagreed with the statement. Only one participant in the 1997 survey did not respond.

Although a high percentage of respondents in both surveys expressed egalitarian attitudes towards American English, when asked to select the country where they thought the best English was spoken, a very small percentage opted for the USA.

As the findings emanating from the 2016 survey reveal, $85.8 \%(n=103)$ of the respondents expressed their view that Britain is the country where the best English is spoken. Only 7.5\% $(n=9)$ chose the United States, $2.5 \%(n=$ 3) Australia, $1.7 \%(n=2)$ Ireland, $1.7 \%(n=2)$ New Zealand and $0.8 \%(n=1)$ South Africa. No one selected Canada. Only one respondent stated that "the best English is spoken nowhere".

The 1997 survey yielded similar results with a slightly higher percentage (91.4\%) of the respondents who chose Great Britain $(n=139)$. Only 5.3\% $(n=$ $8)$ of respondents thought the best English was spoken in the USA, 2\% $(n=3)$ in Canada, $0.7 \%(n=1)$ in Australia, and $0.7 \%(n=1)$ in New Zealand.

Cross-tabulation of the 2016 survey results shows that as many as $86.5 \%$ of the students who reported they spoke American English stated that the best English was spoken in Britain, as did $91.7 \%$ of the respondents who claimed to speak British English. Therefore, the variety that most respondents reported to speak did not influence their responses to this question.

In summary, both surveys yielded similar findings which show that most respondents thought that the 'best' English was spoken in Britain. Although young people are increasingly exposed to American English owing to American popular culture, entertainment media and new electronic technology, British English still retains the aura of being the 'best'. This reverential attitude owes much to the "historicisation" of Standard British English, which requires that "it should possess a continuous unbroken history, a respectable and legitimate ancestry and a long pedigree" (Milroy 2007: 138). Thus, in spite of the fact that "that the centrality of British English is much less clear today" (Horobin 2016: 140), Britain is generally perceived as the foremost cradle of the English language (Stojić 2014), and British English as "the grand daddy of English", as one of the respondents in another study stated (Evans 2005: 243). The Serbian respondents' perceptions may to some extent be influenced by their teachers' attitudes, for in Serbia, as in many other European countries, there are some teachers of English who still maintain that British English should be the only model to be taught in schools (see e.g. Čorbić 2011).

These findings are in line with those obtained from many other attitudinal studies conducted amongst non-native speakers, which have also indicated that standard British English accents (especially RP) enjoy greater prestige than American English accents (e.g. Jarvella et al 2001, Ladegaard and Sachdev 2006, Paunović 2009, Rindal 2010, Evans and Imai 2011, Pilus 2013, Stojić 2014).

When asked about the influence of Americanisms on British English, $20 \%$ of the 2016 survey respondents stated that Americanisms polluted British English (vs. 30.9\% in 1997), only 9.2\% thought they enriched it (vs. 12.5\% 
in 1997), whereas 70\% respondents expressed the opinion that Americanisms neither polluted nor enriched British English (vs. 56.6\% in 1997) (see figure 2).

Figure 2 THE INFLUENCE OF AMERICANISMS ON BRITISH ENGLISH

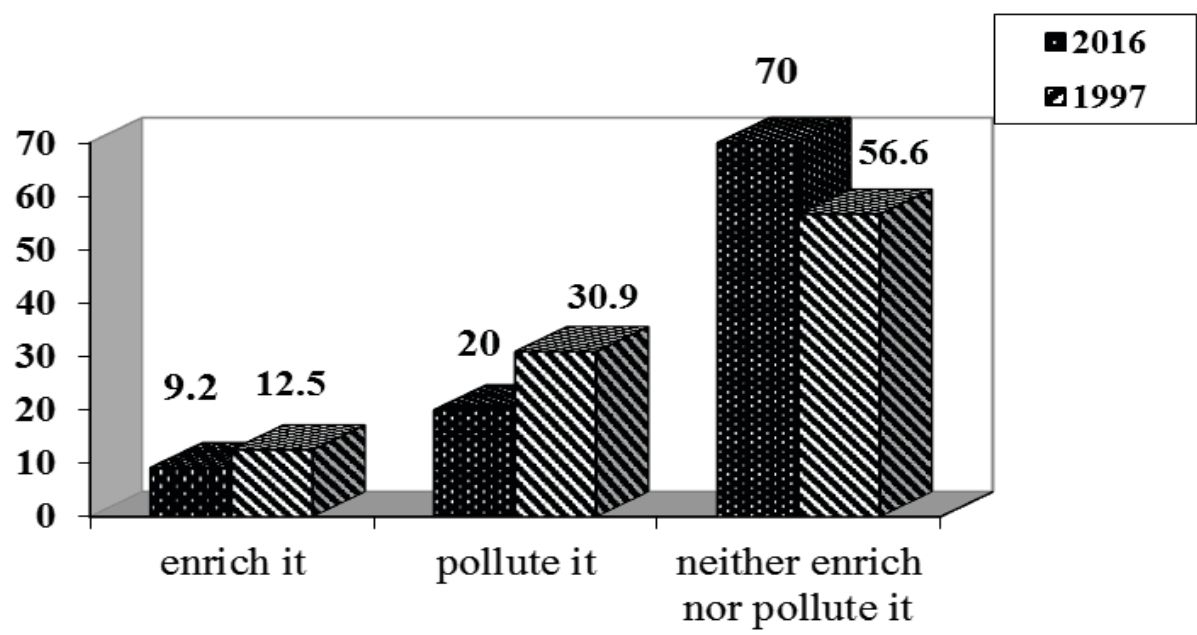

As can be seen, only a very small percentage of respondents in both surveys stated that Americanism enriched British English. The fact that the majority expressed neutral attitudes towards the influence of Americanisms on British English should not be a cause for celebration, for these attitudes may suggest a lack of knowledge about the very purpose of linguistic borrowing. The results showing that a smaller percentage of respondents in the 2016 survey than in the previous one expressed the view that Americanisms polluted British English are not comforting either. These respondents make up one fifth of the sample and many of them are prospective teachers who will further transmit puristic attitudes towards Americanisms without really being able to differentiate them from Briticisms, Australianisms, Canadianisms, etc. Although Americanisation of English provokes debate and complaints in many English-speaking countries, Burridge and Stebbins (2016: 383) point out that "puristic endeavours promote a kind mental dishonesty, and those who attempt them soon find themselves up to their neck in contradiction".

The next set of questions referred to the varieties of English in Great Britain, more specifically to the notion of 'the best' English and the most socially acceptable accent.

Answering the close-ended question 'Who speaks the best English?', almost half of respondents (45.8\%) in the 2016 survey chose BBC newsreaders, $28.3 \%$ selected actors, $16.7 \%$ the Royal family, $4.2 \%$ teachers, whereas no one chose politicians. Two respondents did not answer the question, one of whom wrote that "the best English does not exist". Since the option 'other (please specify)' was offered, four respondents gave the following answers: scientists, Elton John, working class, Benedict Cumberbatch. 
The data emanating from the 1997 survey revealed a somewhat different picture, for $70.5 \%$ of respondents selected the BBC newsreaders while $10.5 \%$ chose the Royal Family, 9.2\% teachers, 7.2\% actors and 2\% of respondents selected politicians. One respondent stated that "no one speaks the best English" (see figure 5).

Figure 5 Who speaks the best English?

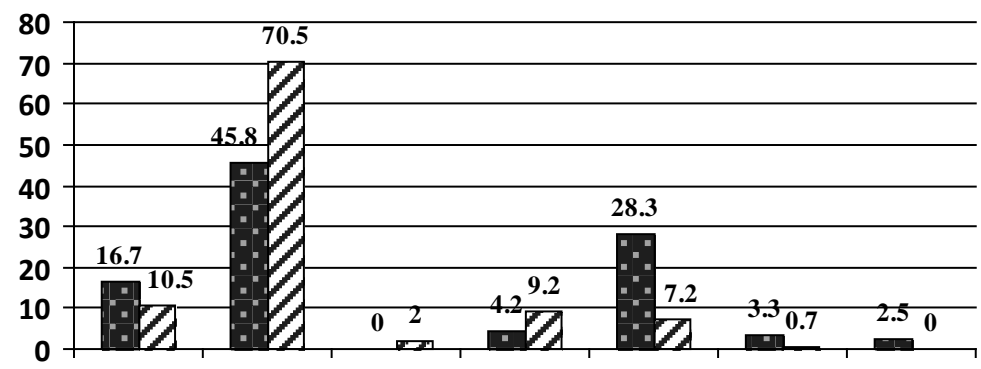

the Royal Family ${ }_{B B C}$ newsreaders politicians teachers actors other no answer

Overall, the results show that a much higher percentage of the 1997 survey respondents thought the BBC newsreaders spoke the best English as compared to those in the 2016 survey, amongst whom a higher percentage expressed preference for the speech styles used by the Royal Family and actors. The differences in responses may be explained by the changing policy of the BBC concerning the use of RP. Thus, it is becoming increasingly common nowadays to hear $\mathrm{BBC}$ newsreaders with regional accents, which still annoys some native speakers and makes them complain (see e.g. Hodson 2014: 29).

To the open-ended question 'In which part of Britain people speak the best English', the 2016 survey respondents gave the following answers: London (50.8\%), the south (21.7\%), the southeast of England (5.8\%), the north of Britain (5.8\%) and England (4.2\%). Only one respondent stated she did not know, whereas $10.8 \%(n=13)$ did not answer the question, one of whom stated "nowhere".

The 1997 survey participants offered a slightly more diversified array of responses, stating that the best English was spoken in: England (26.3\%), London (15.8\%), the south-east of England (15.1\%), central England (5.3\%), Scotland (5.3\%) and Oxford 2.6\%. Four respondents offered the following answers: the north of England, Parliament, universities, and theatres. While 8.6\% $(n=$ 13) of the respondents stated that they did not know, $18.4 \%(n=28)$ did not answer the question at all.

To sum up, a very high percentage of respondents in both surveys stated that the best English was spoken in England. Moreover, a smaller percentage of the 1997 survey respondents and a much higher percentage of those in the 2016 survey were even more specific, locating the best English in the 
south and southeast of England where, historically speaking, Standard English originated.

The question asking the respondents to identify the most socially acceptable accent of English was also open-ended. While 18.3\% of the 2016 survey participants did not answer the question, others offered the following responses: RP (30\%), Southern British Standard (SBS) (19.2\%), standard British (8.3\%), Standard Southern British (SSB) (7.5\%), Cockney (5\%), BBC (4.2\%), Queen's English (1.7\%), British (1.7\%) and Standard English (1.7\%). Three respondents answered in the following way: London, South Britain, all regional dialects.

While $21.7 \%$ of the 1997 survey participants did not respond and $4.6 \%$ claimed they did not know, $36.2 \%$ stated that the most socially acceptable accent was RP, whereas for other respondents it was BBC (17.8\%), Standard English 9.2\%, British (5.3\%), Cockney (2.6\%) and an upper-class accent (1.3\%). One respondent claimed it was a "literary" accent.

As can be seen, the respondents from both surveys offered different designations for the most socially acceptable accent in Britain. The results obtained in the 1997 survey differ primarily from the more recent one in that no respondent mentioned SBS and SSB, although these two labels had already existed at the time (cf. Wells 1982: 117).

Linguists themselves sometimes express different preferences for a particular designation of a standard accent. For instance, Hughes and colleagues (2013: 3) think that the label RP "has acquired a rather dated - even negative - flavour in contemporary British society" and that many linguists "in recognition of the changes to the phonetic properties of RP and its social status over recent decades, prefer the less evaluative term Standard Southern British English (SSBE)". For similar reasons, in the aforementioned survey, the labels such as 'Queen's English' and 'A standard accent of English' were used instead of RP (for an explanation see Coupland and Bishop 2007: 77). Yet there are those who still prefer to label Standard English accent as RP. For example, Brooks (2015: 13) explains that although "some linguists have re-named it 'Southern British Standard' (SBS), or 'Standard Southern British', or even 'General British", he has chosen the term RP "because it is more widely known".

\section{CONCLUSION}

The main purpose of this paper has been to present and analyse some of the findings, yielded by two questionnaire-based surveys carried out in 1997 and 2016 amongst first-year students of English.

The comparison of the results detailed above has mainly demonstrated similar perceptions and attitudes expressed by the two generation of students. The majority in both surveys (although a higher percentage of the 2016 survey participants) expressed positive attitudes towards American English. Yet these attitudes seem to become ambivalent when compared to the attitudes expressed towards British English, which, being perceived as the 'best', stands out above all other national varieties. 
Ambivalent attitudes towards American English are also revealed in responses to the influence of Americanism on British English by both groups of respondents. The attitudes are coloured with a tinge of linguistic purism and a lack of knowledge about linguistic borrowing. Therefore, students of English, many of whom are prospective teachers, should be informed that "all language is language in contact" (Watts 2011: 96), and should be instructed about the processes and reasons of linguistic borrowing. For Americanisms are not just useless, and in the eyes of many respondents, harmless intruders, nor is British English a glass-cased museum exhibit that must not be touched even by its nearest cousin.

The contrasting of findings has also shown that the myth of the 'best' English dies hard. Not only did a very large majority of respondents in both surveys think the 'best' English was spoken in Britain, and more specifically in England, but a higher percentage of them also readily selected particular groups of people (or individuals) who, they thought, spoke 'the best' English. A very high percentage of both survey respondents also stated that the most acceptable accent in Britain was a Standard English accent although they provided a variety of different labels for it.

The comparison of the results related to all the above-mentioned perceptions of and attitudes towards American English and British English expressed by the two generations of students indicates that very little has changed over the years. Moreover, the findings indicating the perceived status and prestige of British English and RP expressed by the majority of respondents are similar to those revealed in various other studies mentioned above.

As it has already been emphasised, the only striking but unsurprising difference between the results of the two surveys has been revealed in students' responses concerning the variety of English they reported speaking. The findings indicating that almost two thirds of the 2016 survey respondents claimed they spoke Standard American English, as compared to only 15.8\% in the 1997 survey, may be of use to teachers and educators when deciding which variety to recommend or use as a teaching model.

New times and new circumstances brought about by globalisation require new pedagogical and social practices that should prioritise the raising of sociolinguistic awareness about varieties of English and language variation in general not only in teacher education and ELT, but in educational broadcast media as well.

\section{References}

Androutsopoulos 2014: J. Androutsopoulos, Mediatization and sociolinguistic change. Key concepts, research traditions, open issues, in: J. Androutsopoulos (ed), Mediatization and Sociolinguistic Change, Berlin/Boston: Walter de Gruyter, 3-48.

Bilankov 2002: T. Bilankov, Korelacija izmedju medijske izloženosti engleskom jeziku i motivisanosti srednjoškolaca za učenje tog jezika, Nastava i vaspitanje, 51(5), 412-420. 
Bishop et al 2005: H. Bishop, N. Coupland, P. Garrett, Conceptual accent evaluation: Thirty years of accent prejudice in the U.K., Acta Linguistica Havniensia, 37, 131-154.

Brooks 2015: G. Brooks, Dictionary of the British English Spelling System, Cambridge, UK: Open Book Publishers.

Burridge, Stebbins 2016: K. Burridge, T.N. Stebbins, For the Love of Language: An Introduction to Linguistics, Melbourne: Cambridge University Press.

Coupland, Bishop 2007: N. Coupland, H. Bishop, Ideologised values for British accents, Journal of Sociolinguistics, 11(1), 74-93.

Čorbić 2011: I. Čorbić, Image, Reality and Standard Language, in: N. Tomović, J. Vujić (eds), English Language and Literature Studies: Image, Identity, Reality, ELLSIIR Proceedings Volume I, Faculty of Philology, Belgrade University, 401-410.

Dragojevic et al 2016: M. Dragojevic, D. Mastro, H. Giles, A. Sink, Silencing nonstandard speakers: A content analysis of accent portrayals on American primetime television, Language in Society, 45, 59-85.

Eagly, Chaiken 2007: A. H. Eagly, S. Chaiken, The advantages of an inclusive definition of attitude, Social Cognition, 25, 582-602.

Eagly, Chaiken 2014: A. H. Eagly, S. Chaiken, Attitude research in the 21st century: The current state of knowledge, in: D. Albarracín, B. T. Johnson, M. P. Zanna (eds), The Handbook of Attitudes, New York/London: Psychology Press, 743-767.

Edwards 2016: A. Edwards, English in the Netherlands: Functions, forms and attitudes, Amsterdam/Philadelphia: John Benjamins Publishing Company.

Evans 2005: B. E. Evans, The grand daddy of English: US, UK, New Zealand and Australian students' attitudes towards varieties of English, in: N. Langer, W. V. Davies (eds), Linguistic Purism in the Germanic Languages, Berlin: Mouton de Gruyter, 240-251.

Evans, Imai 2011: B. E. Evans, T. Imai, 'If we say English, that means America': Japanese students' perceptions of varieties of English, Language Awareness, 22(4), 315-326.

Garrett 2010: P. Garrett, Attitudes to Language, Cambridge: Cambridge University Press.

Galloway, Heath 2015: N. Galloway, R. Heath, Global Englishes, Oxon/New York: Routledge.

Giles 1970: H. Giles, Evaluative reactions to accents, Educational Review, 22, 211-27.

Giles, Marlow 2011: H. Giles, M. L. Marlow, Theorizing Language Attitudes: Existing Frameworks, an Integrative Model, and New Directions, in: C. T. Salmon (ed), Communication Year Book 35, New York: Routledge, 161-197.

Giles, Rakić 2014: H. Giles, T. Rakić, Language attitudes: Social Determinants and Consequences of Language Variation, in: T. M. Holtgraves (ed), The Oxford Handbook of Language and Social Psychology, New York: Oxford University Press, 11-23.

Hodson 2014: J. Hodson, Dialect in film \& literature. London: Palgrave Mcmillan.

Horobin 2016: S. Horobin, How English Became English: A Short History of a Global Language. Oxford: Oxford University Press.

Hughes et al ${ }^{5}$ 2013: A. Hughes, P. Trudgill, D. Watt, English Accents and Dialects: An Introduction to Social and Regional Varieties of English in the British Isles, Oxon: Routledge. 
Jenkins 2007: J. Jenkins, English as a Lingua Franca: Attitude and Identity, Oxford: Oxford University Press.

Jenkins 2014: J. Jenkins, English as a Lingua Franca in the International University: The Politics of Academic English Language Policy, Oxon/New York: Routledge.

Labov 1966: W. Labov, The Social Stratification of English in New York City, New York: Center for Applied Linguistics.

Ladegaard, Sachdev 2006: H.J. Ladegaard, I. Sachdev, 'I like the Americans... But I Certainly Don't Aim for an American Accent': Language Attitudes, Vitality and Foreign Language Learning in Denmark, Journal of Multilingual and Multicultural Development, 27(2), 91-108.

Lambert et al 1960: W. E. Lambert, R. C. Hodgson, R. C. Gardner, S. Fillenbaum, Evaluational Reactions to Spoken Languages, Journal of Abnormal and Social Psychology, 60, 44-51.

Milroy 2007: J. Milroy, The ideology of the standard language, in C. Llamas, L. Mullany, P. Stockwell (eds), The Routledge Companion to Sociolinguistics, Oxon/ New York: Routledge, 133-9.

Paunović 2009: T. Paunović, Plus ça chage ... Serbian EFL students' attitudes towards varieties of English. Poznań Studies in Contemporary Linguistics 45(4):525-47.

Pilus 2013: Z. Pilus, Exploring ESL Learners' Attitudes towards English Accents, World Applied Sciences Journal, 21, 143-152.

Prćić 2014: T. Prćić, English as the nativized foreign language and its impact on Serbian. English Today, 30, 13-20.

Rindal 2010: U. Rindal, Constructing identity with L2: Pronunciation and attitudes among Norwegian learners of English, Journal of Sociolinguistics, 14(2), 240-261.

Rindal, Piercy 2013: U. Rindal, C. Piercy, Being 'neutral'? English pronunciation among Norwegian learners, World Englishes, 32(2), 211-229.

Stojić 2005: S. Stojić, Standardizacija engleskog jezika: Sociolingvistički i sociopsihološki aspekti, Beograd: Filološki fakultet.

Stojić 2013: S. Stojić, On some students' attitudes towards the English language and its two main varieties, Filološki pregled, XL2, 45-53.

Stojić 2014: S. Stojić, British Culture with an American Variety of English, in: Zoran Paunović (ed), English Language and Literature Studies: Embracing Edges (ELLSEE), Faculty of Philology: University of Belgrade, 185-196.

Trudgill 1974: P. Trudgill, The Social Differentiation of English in Norwich, Cambridge: Cambridge University Press.

Trudgill, Hannah 52013: P. Trudgill, J. Hannah, International English: A Guide to Varieties of English, Oxon/New York: Routledge.

Watts 2011: R. J. Watts, Language Myths and the History of English, Oxford: Oxford University Press.

Wells 1982: J.C. Wells, Accents of English 1: An Introduction, Cambridge: Cambridge University Press. 


\section{Svetlana R. Stojić \\ ZNAM GDE SE GOVORI NAJBOLJI ENGLESKI: PERCEPCIJE I STAVOVI JEDNOG BROJA STUDENATA IZ SRBIJE O VARIJETETIMA ENGLESKOG JEZIKA}

U radu su predstavljeni neki od rezultata dva anketna istraživanja o stavovima i percepcijama studenata o varijetetima engleskog jezika. Ankete su sprovedene putem istog upitnika, 1997. i 2016. godine. Glavni cilj ovog komparativnog istraživanja je da se utvrde sličnosti i razlike u eksplicitno izraženim stavovima i percepcijama dve generacije studenata prve godine engleskog jezika, koje razdvaja period od devetnaest godina. U fokusu ovog rada su rezultati koji se odnose na stavove prema britanskoj i američkoj varijanti engleskog jezka, kao i na percepcije o 'najboljem' varijetetu engleskog jezika i društveno najprihvatljivijem izgovoru britanske varijante engleskog jezika. Poređenjem rezultata mogu se uočiti izvesne razlike, ali i dve ključne sličnosti: većina ispitanika iz oba istraživanja izražava pozitivne stavove prema američkom engleskom, ali takođe smatra da se najbolji engleski govori u Velikoj Britaniji.

Ključne reči: anketa, jezički stavovi, percepcije, britanski engleski, američki engleski, varijeteti

Примлен 28. децембра 2017. голине Прихваћен 27. марита 2017. голине 